\title{
Skills-related underemployment amongst South Africa's informally employed and self-employed: A case study of Potchefstroom
}

\begin{tabular}{|c|c|}
\hline \multicolumn{2}{|c|}{$\begin{array}{l}\text { Authors: } \\
\text { Mosima Ngwenya }^{1} \text { (D) } \\
\text { Phillip F. Blaauw }^{1} \text { (D) } \\
\text { Anmar Pretorius }^{1} \text { (D) } \\
\text { Carike Claassen }^{1} \text { (D) } \\
\text { Rinie Schenck }^{2} \text { (D) }\end{array}$} \\
\hline \multicolumn{2}{|c|}{$\begin{array}{l}\text { Affiliations: } \\
{ }^{1} \text { School of Economic } \\
\text { Sciences, Faculty of Economic } \\
\text { and Management Sciences, } \\
\text { North-West University, } \\
\text { Potchefstroom, South Africa }\end{array}$} \\
\hline \multicolumn{2}{|c|}{$\begin{array}{l}{ }^{2} \text { DST/NRF/CSIR Chair in Waste } \\
\text { and Society, Faculty of } \\
\text { Community and Health } \\
\text { Sciences, University of the } \\
\text { Western Cape, Cape Town, } \\
\text { South Africa }\end{array}$} \\
\hline \multicolumn{2}{|c|}{$\begin{array}{l}\text { Research Project Registration: } \\
\text { Project Number: } 14 / 3 / 10\end{array}$} \\
\hline \multicolumn{2}{|c|}{$\begin{array}{l}\text { Corresponding author: } \\
\text { Phillip Blaauw, } \\
\text { derick.blaauw@nwu.ac.za }\end{array}$} \\
\hline \multicolumn{2}{|c|}{$\begin{array}{l}\text { Dates: } \\
\text { Received: } 09 \text { Dec. } 2019 \\
\text { Accepted: } 02 \text { Sept. } 2020 \\
\text { Published: } 16 \text { Nov. } 2020\end{array}$} \\
\hline \multicolumn{2}{|c|}{$\begin{array}{l}\text { How to cite this article: } \\
\text { Ngwenya, M., Blaauw, P.F., } \\
\text { Pretorius, A., Claassen, C., \& } \\
\text { Schenck, R. (2020). Skills- } \\
\text { related underemployment } \\
\text { amongst South Africa's } \\
\text { informally employed and } \\
\text { self-employed: A case study } \\
\text { of Potchefstroom. SA Journal } \\
\text { of Human Resource } \\
\text { Management/SA Tydskrif vir } \\
\text { Menslikehulpbronbestuur, } \\
\text { 18(0), a1308. https://doi. } \\
\text { org/10.4102/sajhrm. } \\
\text { v18i0.1308 }\end{array}$} \\
\hline \multicolumn{2}{|l|}{ Read online: } \\
\hline 口ypa & $\begin{array}{l}\text { Scan this QR } \\
\text { code with your } \\
\text { smart phone or } \\
\text { mobile device } \\
\text { to read online. }\end{array}$ \\
\hline
\end{tabular}

Orientation: Mainstream development theory views the informal sector as a shock absorber in an economic crisis. South Africa's informal sector is smaller than that of many developing countries and very little research has investigated underemployment in marginal informal economic activities.

Purpose: This study investigated the prevalence of skills-related underemployment as well as the possible determinants and impact thereof on the income and poverty of car guards, day labourers and waste pickers in Potchefstroom.

Motivation: There is a need to expand the debate on skills-related underemployment to the informal sector in order to improve our understanding of the shock absorber role of the informal sector and the implications of underemployment for the labour market.

Research design and method: A cross-sectional survey design yielded the data for the analysis. Ordinary least square and probit analysis were used as the statistical methods of analyses to answer the three research questions.

Main findings: Almost half $(48 \%)$ of all the respondents experience skills-related underemployment (vocational over-skilling). Age and gender (for car guards), previous formal employment and day labour experience (day labourers) increase the likelihood of skills-related unemployment.

Practical implications: The findings question the shock absorber role of informal employment and self-employment in South Africa in times of economic crisis. Alternative theoretical approaches deserve consideration.

Contribution/value added: The prevalence of skills-related underemployment in the informal sector points towards the inefficient allocation of labour resources in South Africa. The study paves the way for studies with a broader geographical scope and qualitative focus.

Keywords: underemployment; informal sector; day labour; waste picking; car guards.

\section{Introduction}

The South African economy is facing the worst economic downturn since the Great Depression of the 1930s. Thus far, it is estimated that the economy has contracted by $7 \%$ in the wake of the devastating corona virus disease 2019 (COVID 19) pandemic in 2020 (Karrim, 2020). A recent study by 30 social science researchers from five South African universities indicated that around 3 million people have lost their jobs or income streams between February and April 2020. Two million of these are women. The results further indicated that pre-existing inequalities have been exacerbated in this process (Karrim, 2020). The job and income losses found in the study were concentrated amongst already disadvantaged people, including African people, women, lowwage earners and manual labourers (Karrim, 2020). Many of these low-wage earners and manual labourers are informally employed or self-employed. Fourie (2018) stated that one in six labour force participants is employed in the informal sector. This equates to about 5 million people working in the informal sector before the pandemic (Francis \& Valodia 2020).

Mainstream views in development economics postulate that informal employment acts as a shock absorber for the formal economy in the event of an economic crisis (Rogan, 2016; Szirmai, 
2005; Francis \& Valodia, 2020). The argument is that when someone loses a formal job, they take up informal work as informal work is perceived to be free of barriers to entry. Workers will therefore simply move into this part of the economy and undertake some informal activity (Rogan, 2016; Francis \& Valodia, 2020). The assumption is often that job losses in formal sector industries lead to an increase in the number of workers who create their own work through informal self-employment. Internationally, evidence both supports and refutes this claim (Fallon \& Lucas, 2002; Rogan, 2016; Verick, 2010). This contradiction in the evidence suggests that an economic shock or crisis may have different impacts on informal employment, both within and across countries (Rogan, 2016). For example, unlike other developing countries, South Africa has both very high unemployment and relatively low informal employment (Kingdon \& Knight, 2001; Rogan, 2016; Francis \& Valodia, 2020). In addition, the South African informal sector is long term in nature, with limited prospects of a return to the formal sector once the transition to informality is made (Blaauw, Louw, \& Schenck, 2006).

The current economic downturn, therefore, places renewed question marks behind the theoretical shock absorber function of South Africa's informal sector. We hypothesise that the possible prevalence of underemployment in informal employment and self-employment activities renders any unqualified reliance on the informal sector as shock absorber in difficult economic times, a strategy with serious long-term consequences for lives and livelihoods.

The research questions emanating from the above background and hypotheses are as follows:

1. How prevalent is skills-related underemployment in informal employment and self-employment activities in South Africa's local economies?

2. What are the possible factors increasing the likelihood of a day labourer, waste picker or car guard being skillsrelated underemployed?

3. What are the effects that skills-related underemployment may have on the income and poverty levels of the participants in these activities - given the theoretical shock absorber function ascribed to it by orthodox development economics?

The long-term nature of South Africa's informal sector necessitates opening up this research agenda in order to appreciate the effect of long-term unemployment on the informally waged and self-employed. Knowledge about issues of underemployment in the informal sector can help us to improve our appreciation of the shock absorber function of South Africa's informal economy - assisting in tailoring more effective labour market policies. As the economy faces even more uncertainty in the wake of the COVID 19 pandemic, unemployment numbers are increasing. Therefore, the informal sector conversation has to be louder.

Studies involving the informal sector of South Africa have investigated aspects such as barriers to entry, challenges to survival in the informal sector and research into specific informal industry activities. However, very little research has investigated possible underemployment prevailing in marginal lower tier informal economic activities, such as day labouring, car guarding and waste picking (Beukes, Fransman, Murozvi, \& Yu, 2016). This article aims to contribute towards filling the gap in the literature regarding skills-related underemployment in the informal sector.

The main objective following the above research questions is to investigate the prevalence and possible causes and effects of skills-related underemployment in informal employment activities of car guarding, day labouring and landfill waste picking, using Potchefstroom as a case study. The overarching motivation of the article is to improve our understanding of the South African informal economy's role as shock absorber in times of economic distress, stimulate debate on skillsrelated underemployment in the informal sector and create a platform for future studies to investigate finer nuances that could not be captured in this study.

Felstead and Green (2003) describe skills-related underemployment as a mismatch between an employee's skills and the skills that are required for them to conduct their job. The skills in question can either be of an educational or vocational nature; both of which can further be classified as overeducation or over-skilling, respectively (Beukes et al., 2016). A more formal definition is provided by the 16th International Conference of Labour Statisticians, which defines skills-related underemployed persons as individuals who, during the week of reference, were both willing and available to change their current employment to one that better utilises their skills (Greenwood, 1999).

The importance of investigating skills-related underemployment in the labour market is highlighted by Beukes et al. (2016) and Gibbons (2016) who argue that although the underemployed receive an income, they can also be susceptible to the same social and economic problems that are encountered by the unemployed, because they do not reach their true earnings potential. If this is the case in the informal economy, we have to re-evaluate the role of the informal economy as shock absorber in difficult economic times. The underemployed also experience low job satisfaction and adverse psychological effects, which negatively impact on their productivity levels (Lu, 2017; Sloane, 2014).

Potchefstroom was selected for this case study because various informal employment activities, including car guarding, day labouring and landfill waste picking, are observed in the town, which makes it an ideal setting for an exploratory study of this kind. The study empirically explored the presence of skills-related underemployment and the possible effects it may have on the income and poverty levels of the participants in these informal employment and self-employment activities. The income and poverty estimations are intended to shed light on the 
impact that skills-related underemployment may have on the welfare and living standards of those employed in these informal sub-sectors. A probit analysis was also conducted to examine factors that could possibly contribute towards skills-related underemployment in these informal sub-sectors. The rest of the article is structured as follows. A review of the limited literature in this field of study is provided; followed by a brief discussion on the theoretical constructs and measurement of skills-related underemployment, research methodology, results, discussion and conclusion.

\section{Literature review}

International literature has extensively researched skillsrelated underemployment in the formal sector (Abel \& Deitz, 2014; Battu \& Zakariya, 2015; Borghans \& De Grip, 2000; Diem, 2015; Feldman, 1996; Felstead \& Green, 2013; McGuinness, 2006; Wilkins \& Wooden, 2011). However, no known studies have been conducted exclusively in the informal sector. Likewise, only a few studies have been conducted in South Africa on this topic, most of which have focused on the formal sector, except for a regression analysis by Beukes et al. (2016). Furthermore, apart from the study conducted by Beukes et al. (2016), in which the informal sector is briefly mentioned, skills-related underemployment in the informal sector of South Africa has not been specifically investigated until now.

\section{Constructs of underemployment}

Skills-related underemployment consists of two distinct sub-constructs: overeducation and over-skilling (Flisi, Goglio, Meroni, Rodrigues, \& Vera-Toscana, 2014). Literature classifies overeducation and over-skilling as separate entities that are not highly correlated and have very little overlap (Battu \& Zakariya, 2015; Flisi et al., 2014; Mavromaras, McGuinness, O’Leary, Sloane, \& Fok, 2007).

Overeducation refers to a situation in which an individual is employed in a job that requires a lower level of education than their actual educational attainment level (McGuinness, 2006; Tsai, 2010).

The other component of skills-related underemployment is over-skilling or skills mismatch. Over-skilling occurs when an individual's skills or work experience are higher than what is required for their current employment (McKee-Ryan \& Harvey, 2011). Over-skilling is also seen as a broader term than overeducation, as it encapsulates various skills, abilities and knowledge that an individual may have accumulated outside of a formal education system (Mavromaras, McGuinness, \& Fok, 2009). The notion of work experience has different levels of relevance for the three informal activities considered in the case study. For example, day labourers can benefit directly if they have experience in the building industry and skills related to bricklaying, etc. However, for car guards, work experience in the security industry may be beneficial.

\section{Skills-related underemployment theories}

The most recurrent theories related to skills-related underemployment are human capital theory, ${ }^{1}$ relative deprivation theory, job competition theory and assignment theory.

Relative deprivation theory posits that people's level of job satisfaction is partly related to their desires and expectations with regard to their employment (Feldman, Leana, \& Bolino, 2002). Job competition theory arguably provides one of the most direct economic models regarding skills-related underemployment. The model proposes that workers are seen as being 'employable' if their level of education, gender or age ranks them high enough to lower training costs for the firm (Borghans \& De Grip, 2000; Herrera \& Merceron, 2013).

Lastly, Sattinger's assignment theory consists of two fundamental concepts. The first claims that activities required in each type of job are different (Sattinger, 2012), and the second aspect is that 'frictions' and information asymmetry in the labour market make it difficult for jobseekers and firms to align the skills sets of jobseekers with the skill requirements of firms (Sattinger, 2012). As Feldman (1996) suggests, this theory is also only indirectly linked to the issue of skillsrelated underemployed amongst the informally wage employed and those who are informally self-employed. There is, therefore, not a singular unambiguous theory linked to skills-related unemployment in the informal economy.

\section{Measuring skills-related underemployment}

According to Wilkins and Wooden (2011), skills-related underemployment, from an educational perspective (overeducation), can be objectively measured using the following approaches, which were proposed by McGuinness (2006):

- Calculating the difference between the mean levels of education of other individuals who are employed in the same occupation as the individual who considers himself or herself to be skills-related underemployed.

- Comparing the individual's education level with the educational level that is required for the job that he or she is employed in.

In terms of over-skilling, Felstead and Green (2013) infer that individuals are classified as skills-related underemployed when their qualifications are higher than what was required of them to obtain employment as well as when they can identify an inability to utilise their skills in their job.

1.Human capital theory is one of the dominant theories that are linked to skillsrelated underemployment (Beukes et al., 2016; Fernando, Fernando, \& Hannif, 2014; Gibbons, 2016). This theory does not directly explain skills-related 2014; Gibbons, 2016). This theory does not directly explain skills-related underemployment but explains the contribution of skills-related underemployment to market failure because it stands in direct contrast to ideal labour marke outcomes (Beukes et al., 2016; Fernando et al., 2014). One does not expect any sor of misalignment such as the one described here in any market underpinned by perfectly competitive markets that does not leave any excess demand or supply of labour (clearing markets), such as Becker's Human Capital model. In light of this point, we do not discuss the human capital theory in further detail here. 


\section{Determinants of skills-related underemployment}

In various studies, economic conditions have been identified as one of the precursors of skills-related underemployment (Abel \& Deitz, 2014; Feldman, 1996; Gibbons, 2016; McKeeRyan \& Harvey, 2011). According to Feldman (1996), negative economic conditions (e.g. the world financial crisis of 2009 or the fallout of the COVID 19 pandemic) that occur at industry or firm level can also lead to an increase in skills-related underemployment through mechanisms that are similar to those associated with economic downturns.

Schoeman, Botha and Blaauw (2010), using data from 1970 to 2004, found that technological changes are one of the main contributing factors to persistently high skills-related underemployment in South Africa. Firms increasingly require higher skilled workers because of transformations in production techniques (OECD, 2014).

The probability of being skills-related underemployed can also be influenced by the type of qualification that an individual has (Abel \& Deitz, 2014). Graduates with more non-specialised degrees, such as liberal arts or business, were up to three times more likely to be skills-related underemployed than those with more specialised degrees such as engineering or nursing (Abel \& Deitz, 2014; Diem, 2015; Iriondo \& Velázquez, 2014). Conversely, having qualifications in mathematics, medicine, engineering and education reduced the probability of skills-related underemployment (Chevalier \& Lindley, 2007).

\section{The effects of skills-related underemployment}

Skills-related underemployment is associated with various adverse effects, the most common of which pertains to income (Herrera \& Merceron, 2013; McGuinness, 2006; Wilkins \& Wooden, 2010). Job dissatisfaction is another negative outcome of skills-related underemployment as postulated by the relative deprivation theory.

Skills-related underemployment theoretically not only affects the individual's current employment outcomes but can also negatively impact the trajectory of their careers. According to McKee-Ryan and Harvey (2011), individuals who incur penalties because of skills-related underemployment often continue to be skills-related underemployed years after their first instance of being underemployed (Abel \& Deitz, 2014; Iriondo \& Velázquez, 2010).

\section{Prevalence of skills-related underemployment}

Skills-related underemployment is more prevalent amongst certain demographic groups and generally affects the most vulnerable portion of the labour market. In terms of gender, women are more affected by skills-related underemployment than men (Diem, 2015). The demographics of skills-related underemployment also extend to race. Similarly, age also influences the propensity of an individual's susceptibility to being skills-related underemployed (Jensen \& Slack, 2003; Virick, 2011).
From a South African perspective, data from the last quarter of 2014 show that skills-related underemployment has increased significantly from 1.5 million in 1995 to 4.3 million in 2014, as a proportion of South Africa's employed labour force (Beukes et al., 2016). Of this portion, black South Africans accounted for a disproportionate share at $81.19 \%$ in 2014 (Beukes et al., 2016). Beukes et al. (2016) also report that South African women experience a higher incidence of skills-related underemployment at $53.3 \%$ as opposed to men at $46.7 \%$.

The majority of skills underutilisation in South Africa is found in the urban formal sector at $64.62 \%$, followed by the urban informal sector at $10.67 \%$ (Beukes et al., 2016). In the aftermath of the COVID 19 pandemic, the magnitude and proportion of the informal sector's share of skills underutilisation are expected to increase as more people are expected to seek employment or self-employment opportunities in the lower tiers of the informal sector such as day labouring, waste picking and car guarding. This may have adverse consequences for the ability of the informal economy to act as a shock absorber in this crisis. In terms of occupations, those who work in 'elementary occupations' as well as domestic workers reported the highest incidence of skills-related underemployment at $55.6 \%$ and $14.75 \%$, respectively (Beukes et al., 2016).

The prevalence of skills-related underemployment in South Africa, as per the finding of Beukes et al. (2016), is indicative of its endemic presence in both the formal and the informal labour markets of South Africa. However, an empirical approach will have to be employed in order to draw parallels between the existing theory and the skills-related underemployment in the informal sector.

\section{Research design}

Research approach

A quantitative approach in the form of a cross-sectional survey design was appropriate to seek answers for the study's research questions. Each of the three informal activity groupings was interviewed one after the other within the same municipal area, for example, Potchefstroom.

\section{Research method}

The cross-sectional methodology that is employed in this study follows the structure and survey design used by researchers who have investigated the same informal subsectors that are explored in this study (Blaauw \& Bothma, 2003; Schenck \& Louw, 2005; Viljoen, Blaauw, \& Schenck, 2018). Blaauw and Bothma (2003) used a cross-sectional survey and interviewed all available car guards in Bloemfontein using a questionnaire with closed- and openended questions. Schenck and Louw (2005) explored the socio-economic circumstances of day labourers in Elardus Park (Pretoria) using a similar approach and research design. Viljoen et al. (2018) interviewed almost 1000 waste pickers across South Africa using a cross-sectional survey with a questionnaire that was piloted in a study in Pretoria (Schenck \& Blaauw, 2011) before their countrywide study. 


\section{Measuring instrument}

Klinck and Swanepoel (2019) confirm the importance of a suitable questionnaire as critical for collecting data to answer, prove or disapprove a given research question. The article uses quantitative cross-sectional data collected through questionnaires that were designed in accordance with the format used in the car guard study of Blaauw and Bothma (2003) and used in other day labour (Blaauw et al., 2006; Schenck \& Louw, 2005) and waste picker research (Viljoen et al., 2018). The questionnaires for this study were piloted by these authors (some of whom are also involved in this study) and extensively used in various previous surveys amongst these three groupings of the informal economy in the last decade (see e.g. Viljoen et al. (2018) and Blaauw et al. (2006) for a detailed exposition of the development of these survey instruments). The aforementioned studies can therefore be regarded as a precursor and pilot study for this study of the three sub-sectors of informal employment in the local economy of Potchefstroom. In the procedure that was followed, both quantitative and qualitative data were collected at the same time in each survey.

\section{Research procedure and ethical considerations}

Fieldworkers were recruited to conduct the surveys and relevant training was provided to them by the authors. The fieldwork commenced in phases from October 2014 (car guard surveys amongst 47 car guards), November and December 2014 (71 day labour surveys) until March 2016 when the landfill waste pickers (17) were interviewed. On each occasion, all the car guards, day labourers and waste pickers who were encountered were asked whether they would be willing to participate. The response rate was more than $90 \%$, with very few possible respondents not willing to participate. Even though the absolute numbers of each sample is relatively small, more than $90 \%$ of the research population were included in each sample. This provided an important measure of reliability for the results. The chosen statistical techniques were all appropriate for the number of observations with enough degrees of freedom in each case. All required ethical clearances were obtained and accepted ethical principles were followed at all times.

\section{Statistical analysis: Estimation techniques and underemployment classification scheme}

The study employs three estimation techniques, namely, ordinary least square (OLS), probit analysis and correlation matrices. The use of income as a dependent variable in the OLS regression is to provide answers to the third research question, for example, what effects skills-related underemployment may have on the income and poverty levels of the informally employed and self-employed in the sample. It is further motivated by the consistently negative income effect that is linked to skills-related underemployment in various studies (Herrera \& Merceron, 2013; McGuinness, 2006; Wilkins \& Wooden, 2010).
The probit analyses are primarily aimed at firstly identifying determinants that could possibly increase the likelihood of being skills-related underemployed, and secondly the potential role that skills-related underemployment could play in increasing the likelihood of living below the poverty line as an informal worker. Lastly, correlation matrices were used for the waste pickers group because of sample size restriction; only 17 respondents were found (the day when the fieldwork was attempted, it was raining heavily ), which impedes the probability of making meaningful inferences through regression analysis.

To estimate the poverty probit regressions, minimum poverty thresholds were selected for each informal sub-sector according to the year in which the data were collected. In terms of the car guarding and day labouring poverty probit analyses, the study uses a poverty line of R1252.00, which is based on the 2014 March per capita poverty line provided by Budlender, Leibbrandt and Woolard (2015). R1307.00 is the poverty line that was selected for the waste pickers' income analysis; this is based on the March 2015 poverty line, which was constructed by Budlender et al. (2015). The use of these poverty lines is motivated by the fact that these minimum poverty thresholds were estimated according to a 'subsistence level of living' based on food and non-food items (Budlender et al., 2015).

For the purpose of estimating the proposed regressions, a classification scheme was designed to create an underemployment variable in accordance with the definition of skills-related underemployment as well as the objectives of this study. The variable 'under', as it is used in this study, represents skills-related underemployment in the form of a dummy variable, where 1 is assigned to respondents who are classified as being skills-related underemployed and 0 is assigned to those who are 'adequately' employed.

Table 1 gives an outline of the classification framework and the rationale behind each binary assignment. This is followed by an empirical section that details the estimation results and a discussion of each finding.

\section{Empirical analysis: Results and interpretation}

\section{Type of skills-related underemployment in each informal sub-sector}

The type of skills-related underemployment that is prevalent in each informal sub-sector was determined by comparing the percentage of skills-related underemployed respondents who were overeducated with those who were over-skilled. The baseline for overeducation was set at secondary school attainment, whilst over-skilling included both formal vocation training and informal vocational training. ${ }^{2}$ One can argue that given the type of job, no education is needed. Studies have shown that in some instances the level of education can play a role in the income of day labourers as it enhances communication skills (Blaauw et al., 2006).

2.Informal vocational training within the context of this study refers to various vocational skills that the person acquired through on the job training but for which he or she did not receive a certificate or diploma from an accredited training institute. 
TABLE 1: Skills-related underemployment classification scheme.

\begin{tabular}{|c|c|c|}
\hline Respondent & Assignment & Rationale \\
\hline $\begin{array}{l}\text { No education or } \\
\text { vocational training. }\end{array}$ & Binary value 0 . & $\begin{array}{l}\text { The individual is neither overeducated nor } \\
\text { over-skilled. }\end{array}$ \\
\hline $\begin{array}{l}\text { Some primary } \\
\text { schooling but no } \\
\text { vocational training. }\end{array}$ & Binary value 0 . & $\begin{array}{l}\text { The individual is not overeducated or } \\
\text { over-skilled. }\end{array}$ \\
\hline $\begin{array}{l}\text { Some secondary } \\
\text { schooling but no } \\
\text { vocational training. }\end{array}$ & Binary value 0 . & $\begin{array}{l}\text { Individuals who did not complete their } \\
\text { secondary schooling or vocational training } \\
\text { are not skilled enough to be classified as } \\
\text { underemployed (Beukes et al., 2016, p. 19). }\end{array}$ \\
\hline $\begin{array}{l}\text { Some secondary } \\
\text { schooling and } \\
\text { vocational training. }\end{array}$ & Binary value 1 . & $\begin{array}{l}\text { Individuals are over-skilled because of their } \\
\text { vocational training. }\end{array}$ \\
\hline $\begin{array}{l}\text { Secondary schooling } \\
\text { completed. }\end{array}$ & Binary value 1. & $\begin{array}{l}\text { Individuals are overeducated because they } \\
\text { could acquire a formal sector job with this } \\
\text { qualification alone. }\end{array}$ \\
\hline Tertiary qualification. & Binary value 1 . & $\begin{array}{l}\text { The individual is overeducated for these } \\
\text { informal sub-sectors. }\end{array}$ \\
\hline Vocational training. & Binary value 1 . & $\begin{array}{l}\text { The individual is over-skilled for these } \\
\text { informal sub-sectors. }\end{array}$ \\
\hline
\end{tabular}

TABLE 2: Type of skills-related underemployment. ${ }^{3}$

\begin{tabular}{lcc}
\hline Sub-sector & Over-skilled (\%) & Overeducated (\%) \\
\hline Car guards & 32 & 17 \\
Day labourers & 45 & 12 \\
Waste pickers & 85 & 15 \\
\hline
\end{tabular}

The same applies to waste pickers as the ability to focus on the recyclables with the most value and comparing different buy-back centres with differentiated prices may benefit from improved education levels (Viljoen et al., 2018). We, therefore, included it in the study in the interest of completeness.

Table 2 shows that a disproportionate number of waste pickers are skills-related underemployed because of their vocational skills qualifications and the accompanying effect in the definition used. Only a small portion of the respondents in each sub-sector have completed secondarylevel schooling. The results show that over-skilling, as opposed to overeducation, is the main form of skills-related underemployment across all three sub-sectors.

\section{Ethical consideration}

Senate Research Committee of the University of the Western Cape approved the methodology and ethics of the following research project by: Prof. C. Schenck (Social Work), Research Project: The socio economic aspects of day laboring in South Africa. Registration no: 14/3/10. Any amendments, extension or other modifications to the protocol must be submitted to the Ethics Committee for approval.

The Committee must be informed of any serious adverse event and/or termination of the study. Ethical Clearance was received on 17 June 2014.

\section{Empirical results: Research questions 1-3}

All estimated regressions were first corrected for heteroscedasticity using the White's adjustment option, and

3.Looking at the sensitivity of these numbers to different definitions of 'over' would have been the ideal. This is unfortunately not possible, given the characteristics of the research population and the type of data we were able to collect. The measure used therefore constitutes the most practical measure in the context of this study. probit analyses were adjusted using the Huber/White standard errors and covariance adjustment. The results of all three sub-sectors are first provided in three sections, followed by a general discussion and comparison of results across all three informal sub-sectors.

To rationally analyse all three models (income, underemployment and poverty) used to answer research questions 2 and 3, the presence and extent of skills-related underemployment had to be established (research question 1). The proportion of underemployed respondents was calculated as the number of respondents who were classified as being skills-related underemployed, according to the framework provided in Table 1, as a percentage of the total number of respondents in each sample. Based on this, more than $48 \%$ of the respondents across all three informal subsectors were found to be underemployed. The highest incidence was in the informal car guarding sector $(74 \%)$, which could be a result of the basic security qualification that is required to formally operate as a car guard.

The explanatory variables used in the income and probit models (for research questions 3 and 2, respectively) were chosen from the survey questions that were deemed most applicable to each sub-sector. The income models use the calculated average monthly income. The dependent variable for the poverty models is a binary variable where 1 was assigned to respondents whose average monthly income placed them below the poverty threshold, and 0 to those who were above it. Results from the income and poverty models will give an indication of the potential impact that skills-related underemployment could possibly have on the living standards and welfare of the respondents (research question 3). Lastly, the underemployment models used the previously classified dummy variable 'under' to identify possible factors that might have led to underemployment amongst some of the respondents of these informal sectors (research question 2).

\section{The car guarding sub-sector}

Race and gender were not included in the income equations of the car guarding sector because their distributions were severely skewed, which negatively affected the models; $68 \%$ of the respondents are black and $77 \%$ are male. Similarly, educational attainments lower than secondary school were combined into one dummy variable (dumlowed), which allows for a more even distribution of the education variable. In terms of the age of the respondents, dummy variables were created to capture the possible age group effects; ' $y o u n g$ ' refers to the age group 18-24, 'middage' refers to age group 35-50 and 'old' refers to age group of 50 and older for the purpose of this study. Age was also deconstructed for the underemployment probit analysis. The dummy variable 'vul_age' represents respondents who are categorised as being either young or old because these age groups are more susceptible to skills-related underemployment (Jensen \& Slack, 2003; Virick, 2011). 
TABLE 3: Car guarding: Income effects, determinants of underemployment and likelihood of increased poverty.

\begin{tabular}{|c|c|c|}
\hline Independent variables & Coefficient & $p$ \\
\hline \multicolumn{3}{|c|}{ Dependent variable: Income model: OLS } \\
\hline Constant & -1293.839 & 0.301 \\
\hline Workdays & 483.981 & $0.076^{*}$ \\
\hline Formal & 1583.549 & $0.006 * * *$ \\
\hline Under & -1289.547 & $0.075^{*}$ \\
\hline Young & 1502.720 & $0.006 * * *$ \\
\hline Lowed & 1394.256 & $0.087^{*}$ \\
\hline$R^{2}$ & 0.355 & NA \\
\hline F stat & 3.7135 & $0.002 *$ \\
\hline \multicolumn{3}{|c|}{ Dependent variable: Underemployment model: PROBIT } \\
\hline Constant & -0.305 & 0.584 \\
\hline Work_exp & -0.052 & 0.114 \\
\hline Vul_age & 1.233 & $0.041^{* *}$ \\
\hline Formal & 0.197 & 0.688 \\
\hline Male & 0.961 & $0.094 *$ \\
\hline NA & NA & NA \\
\hline Mcfadden $R^{2}$ & 0.215 & NA \\
\hline LR stat & 8.476 & $0.075^{*}$ \\
\hline \multicolumn{3}{|c|}{ Dependent variable: Poverty model: PROBIT } \\
\hline Constant & 1.638 & 0.434 \\
\hline Workdays & -0.125 & 0.692 \\
\hline Formal & 0.054 & 0.904 \\
\hline Age & -0.000 & 0.698 \\
\hline Under & 0.227 & 0.845 \\
\hline NA & NA & NA \\
\hline Mcfadden $R^{2}$ & 0.008 & NA \\
\hline LR stat & 0.348 & 0.986 \\
\hline
\end{tabular}

Other regressors in the models are the number of days the car guard works (workdays), a dummy variable (formal) that shows whether they work as a formal or informal car guard as well as their years of work experience (work exp); the dummy variable 'male' is included in the underemployment probit analysis. Table 3 gives a summary of the effect of skills-related underemployment on income, the determinants that increase the likelihood of being skillsrelated underemployed and the potential role of skillsrelated underemployment in increasing the likelihood of living below the poverty line. ${ }^{4}$

According to the OLS model (with income as dependent variable to investigate research question 3), the number of days worked, working as a formal car guard, being skillsrelated underemployed as well as educational attainment all have a statistically significant relationship with the income of the car guards. The robustness of these variables is further substantiated by Models 1 and 2 in Appendices 1 and 2. This confirms a possible relationship between the income of the car guards and the three variables. Skillsrelated underemployment has a negative and weakly significant relationship with income in this sub-sector, for example, skills-related underemployment may be reflected in the levels of income earned by car guards in the sample.
The underemployment probit shows that only age and gender have a statistically significant relationship with the probability of being skills-related underemployed in the car guarding sector. The sign of the age dummy is positive, which seems to indicate that being a younger or older car guard (vulnerable age) could possibly increase the likelihood of being skills-related underemployed in the Potchefstroom car guarding sector. However, the sign of the male dummy is positive, which is contrary to underemployment theory. This could be attributed to the distribution problems that are associated with this variable in the data set or because the likelihood of being underemployed according to gender 'varies across demographics and work-related factors' (Beukes et al., 2016). The poverty probit found that none of the hypothesised variables have a significant relationship with the poverty levels of the car guards.

\section{The day labouring sub-sector}

The income variable for the day labouring sub-sector is based on information provided by day labourers regarding their best monthly income during the year of reference. The variable 'negotiated' is a dummy variable that shows whether a day labourer negotiated wages with a potential employer and 'reserve' represents the reservation wage of each respondent. Variables indicating whether a day labourer was recently hired as a bricklayer, painter or plumber are also included based on the findings that day labourers' wages can be positively influenced by this factor (Blaauw et al., 2006)

The variable 'primary' was included to determine the possible impact of education on day labourers' wages, and the variable 'under' represents skills-related underemployment. Furthermore, the years of experience as a day labourer are also included (dl_exp) under the assumption that a day labourer who has many years of day labouring experience has a higher probability of being employed and receives good wages than day labourers with fewer years of day labouring experience.

In addition to the variables that are used for the wage model, the variable 'fulltime' is used in the underemployment probit analysis as a proxy variable, which represents years of experience as a previous formal sector employee. The underlying rationale behind this is that having experience in the formal sector increases the likelihood of being skillsrelated underemployed, and this could also be the case in the informal sector. Likewise, years of day labouring experience (dl_exp) are also included in this model to assess the impact of additional years of experience on the likelihood of day labouring experience. Using these work experience variables is also supported by the findings of Beukes et al. (2016) who established 'a significantly convex relationship between years of work experience and the likelihood of underemployment'.

The poverty probit analysis uses 'person-specific' attributes, which could possibly contribute towards the poverty levels of the day labourers in conjunction with being skills-related 
TABLE 4: Day labouring: Income effects, determinants of underemployment and likelihood of increased poverty.

\begin{tabular}{|c|c|c|}
\hline Independent variable & Coefficient & $p$ \\
\hline \multicolumn{3}{|c|}{ Dependent variable: Income Model: OLS } \\
\hline Constant & -151.226 & 0.807 \\
\hline Negotiate & 627.576 & $0.020 * *$ \\
\hline Reserve & 14.554 & $0.004 * * *$ \\
\hline DI_exp & -44.335 & $0.016^{* *}$ \\
\hline Under & 362.701 & 0.240 \\
\hline Primary & -748.481 & $0.051^{* *}$ \\
\hline H_paint & 354.862 & 0.114 \\
\hline H_plumb & 547.913 & 0.186 \\
\hline H_bricklay & 552.665 & $0.094^{*}$ \\
\hline$R^{2}$ & 0.416 & NA \\
\hline F stat & 3.839 & $0.004 * * *$ \\
\hline \multicolumn{3}{|c|}{ Dependent variable: Underemployment Model: PROBIT } \\
\hline Constant & -0.775 & $0.041^{* *}$ \\
\hline Fulltime & 0.902 & $0.011 * *$ \\
\hline Dl_exp & 0.080 & $0.007^{* * *}$ \\
\hline H_bricklay & -0.028 & 0.935 \\
\hline H_paint & -0.374 & 0.311 \\
\hline H_plumb & 0.039 & 0.914 \\
\hline NA & NA & NA \\
\hline NA & NA & NA \\
\hline NA & NA & NA \\
\hline Mcfadden $R^{2}$ & 0.116 & NA \\
\hline LR stat & 10.666 & $0.058^{* *}$ \\
\hline \multicolumn{3}{|c|}{ Dependent variable: Poverty Model: PROBIT } \\
\hline Constant & 0.214 & 0.765 \\
\hline Negotiate & -0.662 & $0.090^{*}$ \\
\hline Under & 0.459 & 0.226 \\
\hline Primary & 0.906 & $0.030 * *$ \\
\hline Reserve & -0.007 & 0.193 \\
\hline NA & NA & NA \\
\hline NA & NA & NA \\
\hline NA & NA & NA \\
\hline NA & NA & NA \\
\hline Mcfadden $R^{2}$ & 0.147 & NA \\
\hline LR stat & 9.031 & $0.002 * * *$ \\
\hline
\end{tabular}

underemployed. Including these variables could also assist in determining whether the determinants of poverty in the day labouring sector are exogenously or endogenously determined. Table 4 presents the effect of skills-related underemployment on income, the determinants that increase the likelihood of being skills-related underemployed, and the potential role of skills-related underemployment in increasing the likelihood of living below the poverty line.

The results of the income model show that negotiating wages, educational attainment, reservation wage, having day labouring experience and being previously hired as a bricklayer are statistically significantly associated with the day labouring wage market in Potchefstroom. The variables that represent wage negotiation and educational attainment appear to have the biggest impact on obtaining a good monthly wage, because they have the largest coefficients. Furthermore, the signs of the coefficients of both these variables indicate that day labourers, who negotiate their wages and have higher educational attainment than primary school, could receive higher wages. The underemployment variable, although not significant, has a positive sign that could indicate that being underemployed in the day labouring market could have a positive effect on wages. This could be caused by employers preferring to hire an overskilled day labourer as opposed to one with very little skills and experience. The statistical significance of education and work experience in this model emphasises the 'erosion' of income when skills are not adequately employed (Almeida, Fernando, \& Hannif, 2014; Beukes et al., 2016).

Appendices 1 and 2 presents a model using the respondents' worst monthly income as a robustness check for the variables that are statistically significant in this model; educational attainment is the only variable that was not found to be statistically significant in this model. This could be explained by the fact day labourers are typically hired for their vocational skills, and their educational attainment does not play a role in the vast majority of the jobs they are hired for.

The underemployment probit model shows that day labouring experience and previous formal work experience both have a statistically significant link with the probability of being underemployed. The coefficients of both variables also have a positive sign, indicating that having work experience may be associated with the probability of being skills-related underemployed, much like in the formal sector.

According to the results of the poverty probit-model, negotiating wages and educational attainment have a statistically significant relationship with poverty that is found amongst day labourers in Potchefstroom. According to the signs of the coefficients, negotiating wages may reduce the probability of being poor and day labourers with only primary level schooling could have a higher likelihood of living below the poverty line than their more educated counterparts. Reservation wages and underemployment are not, however, significantly associated with poverty in this sector. The fact that underemployment is not statistically significant could signify that there could be labour demand factors that have a larger influence on poverty in this sub-sector.

\section{The waste picking sub-sector}

The waste picker sample consists of only 17 respondents, rendering accurate regression analysis impractical. This section is therefore aimed at a descriptive, as opposed to regression-based analysis. Correlation matrices are, however, used to determine the possible correlations amongst certain choice variables.

The income analysis for the waste pickers was conducted with correlation matrices and was aimed at detecting variables that may be associated with the income levels of the waste pickers. According to Asteriou and Hall (2011), a correlation result of 0.90 is indicative of a significant relationship between variables.

Age,educationalattainment,being skills-related underemployed and having previous work experience in the formal sector were 
TABLE 5: Waste picker correlation matrix: The possible association of skillsrelated underemployment on income.

\begin{tabular}{lcccc}
\hline Income & Age & Educational attainment & Work_exp & Under \\
\hline Good month & -0.32 & 0.10 & 0.10 & -0.14 \\
Bad month & -0.12 & 0.49 & 0.36 & -0.20 \\
\hline
\end{tabular}

selected as possible correlates with income. Variables such as gender and race were not normally distributed and were eliminated to avoid bias. Furthermore, income was calculated based on the respondents' answers regarding their best average income in a good week or a bad week; these were then multiplied by four to arrive at a monthly income. Table 5 presents the results of the waste picker analysis.

According to the results of Table 5, none of the explanatory variables are highly correlated with the income of the waste pickers. The correlation coefficient for underemployment is very low and its sign is negative. Probit models could not be estimated to identify potential determinants of underemployment in this sub-sector because of a lack of variation in the variables of interest; likewise, poverty probit models could not be conducted.

\section{Further discussion and conclusion}

South Africa is in the midst of a global pandemic and the worst economic contraction since the Great Depression of the 1930s (Karrim, 2020). This places renewed focus on the shock absorber function of the informal sector as propagated by orthodox development economic theory. With significant job losses, the expectation is that many of the unemployed will take up temporary employment or self-employment in the informal sector (Rogan, 2016; Szirmai, 2005; Francis \& Valodia, 2020). However, existing literature points out that South Africa has in fact a relatively smaller but more permanent informal sector than other developing countries (Kingdon \& Knight, 2001; Rogan, 2016; Francis \& Valodia, 2020). What has not been researched within the South African context are issues of underemployment within an informal economy context - even though this can potentially impact the viability of the informal sector as shock absorber in times of crisis.

This study investigated skills-related underemployment in three informal sector activities in the local economy of Potchefstroom to determine the presence and prevalence of skills-related underemployment amongst car guards, day labourers and waste pickers as well as investigate the possible determinants of underemployment and its impact on income and poverty levels. The study found that skillsrelated underemployment is present amongst almost half $(48 \%)$ of all the respondents across all three informal subsectors in Potchefstroom. The prevalence of skills-related underemployment in these informal sub-sectors can possibly point towards the inefficient allocation of labour resources in South Africa. The fact that vocational over-skilling is the most prevalent type of skills-related underemployment could be indicative of information asymmetry or job competition in the vocation skills market.
Regarding the second research question, the probit analysis shows that older male car guards have a higher probability of being skills-related unemployed. In the case of day labourers, previous experience in the formal sector and longer day labour experience are positively associated with an increased probability of being skills-related underemployed. The presence and determining factors of skills-related underemployment found in this study highlight the danger of assuming that the informal sector can be a successful shock absorber in this crisis. The issue of underemployment in the informal sector will increase in scope and magnitude as more and more people who lost formal sector jobs attempt to earn some income in activities such as car guarding or informal wage employment (day labouring). This begs the third research question as to what possible impact skills-related underemployment may have on income and poverty levels in these activities.

Results from our empirical analysis show that skills-related underemployment amongst Potchefstroom's car guards is negatively (albeit weakly in terms of statistical significance) associated with income earned. Amongst the day labourers, the relationship is not statistically significant and the sign of the coefficient is actually positive. Given these results, the fact that issues of underemployment are not significantly related to poverty levels is not surprising. Given the small sample size of the waste picker sample, such inferences could not be made.

A number of potential areas for further studies can be identified from the results. One particular issue is looking at the sensitivity of the number of over-skilled informal economy participants to different definitions of 'over-skilled'. Refining the survey instruments can assist in obtaining survey data that allows for this type of analysis. Larger samples across various provinces should also be considered in order to circumvent the limitations of this study's empirical analysis. Furthermore, issues of low levels of job satisfaction and adverse psychological effects related to skills-related unemployment in the informal sector, which negatively impact the productivity levels, need to be investigated as these are important labour market implications from an industrial relations and human resources' perspective and not just the informal sector.

The results of the study ask of us to consider alternative theoretical explanations for the role of the informal sector in the South African economy and labour market. The informal sector's role as shock absorber may be a more limited one in South Africa. The alternative theoretical explanation of an employer of last resort and often the second best alternative to formal employment requires attention too. This being said, the permanent nature and critical role of South Africa's informal sector in providing livelihoods for millions of South Africans, as pointed out recently by Fourie (2018), are not challenged by these results.

Although this is a relatively small study, it is the first study (that we know of) that compared three sets of informal 
workers in one local economic setting. This is an important contribution and point of departure to start understanding the important role of the informal sector in South Africa. More studies covering more local economies such as the metropoles is an important road map for future studies instead of single studies of single groupings, for example, day labourers, waste pickers, car guards and street vendors.

Such studies will point the way to a better theoretical understanding of the uniqueness of the South African context. The advent of car guarding, for example, is not something that formed part of the background when mainstream development economic theories on the informal sector were developed. Furthermore, South Africa has further characteristics such as high levels of migration with informal employment such as day labouring playing a different role within the context of the reception country compared to that of day labouring in the United States (Theodore et al., 2015).

Including different theoretical roles and issues of underemployment in the informal sector in the debate and discourse on the various challenges facing the South African labour market and its participants may enhance the depth of the discussion. This will enhance our understanding of the labour market challenges faced by South Africa beyond the mere snapshot provided when considering unemployment rates and other labour market indicators in isolation.

\section{Acknowledgements}

The authors express their sincere gratitude for the valuable comments received from the anonymous referees of the journal. All mistakes remain our own.

\section{Competing interests}

The authors declare that they have no financial or personal relationships that may have inappropriately influenced them in writing this article.

\section{Authors' contributions}

M.N. did the literature review, the data analysis and wrote the first draft of the results. P.F.B. conceptualised the study, conducted the fieldwork and provided support in the data analysis and the editing of the first draft of the article. C.C. assisted in the conception of the study, conducted the fieldwork and assisted in the editing of the article. A.P. guided the empirical work and writing up of the results. R.S. conducted fieldwork and assisted in editing the first draft of the article. All authors were involved in the editing of the manuscript and the approval of the final version of the article.

\section{Funding information}

The authors gratefully acknowledge the funding received from the study from the DST-NRF Centre of Excellence in Food Security.

\section{Data availability statement}

The data are owned by the NWU.

\section{Disclaimer}

The views expressed in the submitted article are those of the authors and not an official position of the institutions or funders.

\section{References}

Abel, J.R., \& Deitz, R. (2014). Underemployment in the early careers of college graduates following the great recession. New York, NY: Federal Reserve Bank of New York Staff Reports.

Almeida, S., Fernando, M., \& Hannif, Z. (2014). Human capital theory: Explaining the underutilisation of skilled immigrants in Australia. Wollongong: University of Wollongong.

Asteriou, D., \& Hall, S.G. (2011). Applied econometrics. New York, NY: Palgrave MacMillan.

Battu, H., \& Zakariya, Z. (2015). Overskilling and overeducation in Malaysia. Aberdeen, SD: Centre for European Labour Market Research.

Beukes, R., Fransman, T., Murozvi, S., \& Yu, D. (2016). Underemployment in South Africa. Economic Research of Southern Africa, Working Paper no. 575. University of Cape Town.

Blaauw, P.F., \& Bothma, L.J. (2003). Informal labour markets as a solution for unemployment in South Africa - A case study of car guards in Bloemfontein. South African Journal of Human Resource Management, 1(2), 40-44. https://doi. org/10.4102/sajhrm.v1i2.14

Blaauw, P.F., Louw, H., \& Schenck, C.J. (2006). The employment history of day labourers in South Africa and the income they earn: A case study of day labourers in Pretoria. South African Journal of Economic and Management Sciences, 9(4), 458-471. https://doi.org/10.4102/sajems.v9i4.1034

Borghans, L., \& De Grip, A. (2000). The overeducated worker? The Economics of skill utilization. Cheltenham: Edward Elgar Publishing Limited.

Budlender, J., Leibbrandt, M., \& Woolard, I. (2015). South African poverty lines: A review and two new money-metric thresholds. Southern Africa Labour and Development Research Unit, Paper no. 151. University of Cape Town.

Chevalier, A., \& Lindley, J. (2007). Over-education and the skills of UK graduates. London: Centre for the Economics of Education.

Diem, A. (2015). Overeducation among graduates from universities of applied sciences: Determinants and consequences. Journal of Economic and Financial Sciences: Determinants and consequences. Journal of Economidies, 3(2), 63-77. https://doi.org/10.18533/jefs.v3i02.105
Studiention

Fallon, P.R., \& Lucas, R.E.B. (2002). The impact of financial crises on labor markets, household incomes, and poverty - A review of evidence. World Bank Research Observer, 17(1), 21-46. https://doi.org/10.1093/wbro/17.1.21

Feldman, D.C. (1996). The nature of underemployment. Journal of Management, 22(3), 385-407. https://doi.org/10.1177/014920639602200302

Feldman, D.C., Leana, C.R., \& Bolino, M.C. (2002). Underemployment and relative deprivation among re-employed executives. Journal of Occupational and
Organization Psychology, 75(4), 453-471. https://doi.org/10.1348/09631790 Organization
2321119682

Felstead, A., \& Green, F. (2013). Skills in focus: Underutilization, overqualification and skills mismatch: patterns and trends. Edinburgh: Joint Skills Committee.

Flisi, S., Goglio, V., Meroni, E.C., Rodrigues, M., \& Vera-Toscana, E. (2014). Measuring occupational mismatch: Overeducation and overskill in Europe. Evidence from PIAAC. Brussels, BE: European Commission- Joint Research Center.

Fourie, F.C.V.N. (2018). Creating jobs, reducing poverty III: Barriers to entry and growth in the informal sector - And business cycle vulnerabilities. Retrieved from http:// www.econ3 3 3.org/article/creating-jobs-reducing-poverty-iii-barriers-entry-andgrowth-informal-sector- $\% \mathrm{E} 2 \% 80 \% 93$-and-busines

Francis, D., \& Valodia, I. (2020). South Africa needs to focus urgently on how COVID-19 will reshape its labour market. Retrieved from https://www.wits.ac.za/scis/ publications/opinion/sa-needs-to-focus-on-how-covid-19-will-reshape-labourmablications

Gibbons, S. (2016). The lived experience of underemployed first-generation college graduates. Doctoral dissertation. Montreal: McGill University.

Greenwood, A.D. (1999). International definitions and prospects of underemployment statistics. Geneva: International Labour Organization.

Herrera, J., \& Merceron, S. (2013). Underemployment and job mismatch in Sub-Saharan Africa. In P. De Vreyer \& F. Roubaud (Eds.), Urban labor markets in sub-Saharan Africa (pp. 83-107). Washington, DC: World Bank.

Iriondo, I., \& Velázquez, F.J. (2014). The effects of overeducation and overskilling on graduate wages: Evidence from Spain. Madrid: Complutense University of Madrid.

Jensen, L., \& Slack, T. (2003). Underemployment in America: Measurement and evidence. American Journal of Community Psychology, 32(17), 21-31. https://doi. org/10.1023/A:1025686621578

Karrim, A. (2020). Millions have lost their jobs during the lockdown, impacting social welfare and food poverty. Retrieved from https://www.news24.com/news24/ southafrica/news/millions-have-lost-their-jobs-during-the-lockdown-impactingsocial-welfare-and-food-poverty-20200716 
Kingdon, G.G., \& Knight, J. (2001). Why high open unemployment and small informal sector in South Africa? Centre for the Study of African Economies, Department of Economics, University of Oxford. Retrieved from https://pdfs.semanticscholar. org/4ca5/a3a73018fb58a2de59e62dc510140fca92a0.pdf

Klinck, K., \& Swanepoel, S. (2019). A performance management model addressin human factors in the North West provincial administration. SA Journal of Human Resource Management/SA Tydskrif vir Menslikehulpbronbestuur, 17, a1021. https://doi.org/10.4102/sajhrm.v17i0.1021

Lu, M.S. (2017). A study on the phenomenon of overeducation in China and its trend analysis. Open Journal of Social Sciences, 5, 191-204. https://doi.org/10.4236/ jss.2017.51015

Mavromaras, K., McGuinness, S., \& Fok, Y.K. (2009). Assessing the incidence and wage effects of overskilling in the Australian labour market. The Economic Record, 85(268), 60-72. https://doi.org/10.1111/j.1475-4932.2008.00529.x

Mavromaras, K., McGuinness, S., O'Leary, N., Sloane, P., \& Fok, Y.K. (2007). The problem of overskilling in Australia and Britain. Bonn: Institute for the Study of Labour.

McGuinness, S. (2006). Overeducation in the labour market. Journal of Economic Surveys, 20(3), 388-418. https://doi.org/10.1111/j.0950-0804.2006.00284.x

McKee-Ryan, F.M., \& Harvey, J. (2011). 'I have a job, But...': A review of underemployment. Journal of Management, 37(4), 962-996. https://doi. org/10.1177/0149206311398134

OECD. (2014). Preventing unemployment and underemployment form becoming structural. Paris: Organisation of Economic Co-operation and Development.

Rogan, M. (2016). Informal employment and the global financial crisis in a middleincome country. Retrieved from https://www.wiego.org/blog/informal-employmentand-global-financial-crisis-middle-income-country

Sattinger, M. (2012). Assignment models and quantitative mismatches. Albany, NY: University of Albany.
Schenck, C.J., \& Louw, H. (2005). An exploratory study on day labourers in Elardus Park Pretoria. Social Work/Maatskaplike Werk, 41(1), 84-95.

Schenck, R., \& Blaauw, P.F. (2011). The work and lives of street waste pickers in Pretoria - A case study of recycling in South Africa's urban informal economy. Urban Forum, 22(4), 411-430. https://doi.org/10.1007/s12132-011-9125-x

Schoeman, C.H., Botha, I., \& Blaauw, P.F. (2010). Labour conflict and the persistence of macro underemployment in South Africa. South African Journal of Economics and Management Sciences, 13(3), 272-292. https://doi.org/10.4102/sajems.v13i3.23

Sloane, P.J. (2014). Overeducation, skills mismatches, and labour market outcomes for college graduates. Bonn: Institute of Labor Economics.

Szirmai, A. (2005). The dynamics of socio-economic development - An introduction. Cambridge: Cambridge University Press.

Theodore, N., Blaauw, D., Schenck, C., Valenzuela, Jr. A., Schoeman, C., \& Meléndez, E. (2015). Day labor, informality and vulnerability in South Africa and the United States. International Journal of Manpower, 36(1), 807-823. https://doi.org/ 10.1108/IJM-01-2014-0036

Tsai, Y. (2010). Returns to overeducation: A longitudinal analysis of the U.S labor market. Economics of Education Review, 29(4), 606-617. https://doi. org/10.1016/j.econedurev.2010.01.001

Verick, S. (2010). Unravelling the impact of the global financial crisis on the South African labour market. International Labour Office Employment, Working Paper African labour market. International Labour

Viljoen, J.M.M., Blaauw, P.F., \& Schenck, R. (2018). 'Sometimes you don't make enough to buy food': An analysis of South African street waste pickers' income. Journal of Economic and Financial Sciences, 11(1), a186. https://doi.org/10.4102/ jef.v11i1.186

Virick, M. (2011). Underemployment and older workers. In D.C. Maynard \& D.C. Feldman (Eds.), Underemployment: Psychological, economic and social challenges (pp. 81-103). New York, NY: Springer.

Wilkins, R., \& Wooden, M. (2011). Economic approaches to studying underemployment Melbourne: Melbourne Institute of Applied Economic and Social Research. 


\section{Appendix 1: Car guarding models}

TABLE 1-A1: Income models including race and gender.

\begin{tabular}{|c|c|c|}
\hline Variables & Coefficient & $p$ \\
\hline \multicolumn{3}{|l|}{ Model 1} \\
\hline Constant & 693.949 & 0.653 \\
\hline Workdays & 449.090 & $0.069 *$ \\
\hline Formality & 1119.552 & $0.053^{* *}$ \\
\hline Under & -935.063 & 0.234 \\
\hline Female & 366.977 & 0.615 \\
\hline Black & -467.822 & 0.473 \\
\hline NA & NA & NA \\
\hline$R^{2}$ & 0.325 & NA \\
\hline F statistic & 2.818 & $0.003^{* * *}$ \\
\hline \multicolumn{3}{|l|}{ Model 2} \\
\hline Constant & -815.749 & 0.612 \\
\hline Workdays & 244.441 & 0.343 \\
\hline Female & 1155.714 & 0.109 \\
\hline Formality & 1249.904 & $0.032 * *$ \\
\hline Young & 1730.879 & $0.045^{* *}$ \\
\hline Lowed & 1747.935 & 0.119 \\
\hline Black & -522.303 & 0.498 \\
\hline$R^{2}$ & 0.347 & NA \\
\hline$F$ statistic & 2.391 & $0.003 * * *$ \\
\hline
\end{tabular}

NA, not applicable.

*, Significant at $10 \%$.

**, Significant at $5 \%$.

$* * *$, Significant at $1 \%$

TABLE 2-A1: Income robustness models.

\begin{tabular}{lcc}
\hline Variables & Coefficient & $p$ \\
\hline Model 1 & & \\
Constant & -128.740 & 0.926 \\
Workdays & 536.123 & $0.054^{* *}$ \\
Formality & 1478.408 & $0.007^{* * *}$ \\
Under & -1365.203 & $0.058^{* *}$ \\
Young & 720.923 & 0.189 \\
NA & $\mathrm{NA}$ & $\mathrm{NA}$ \\
$R^{2}$ & 0.331 & $\mathrm{NA}$ \\
F statistic & 3.713 & $0.017^{* *}$ \\
Model 2 & & \\
Constant & -1293.839 & 0.301 \\
Workdays & 483.981 & $0.076^{*}$ \\
Young & 1502.720 & $0.006^{* * *}$ \\
Formality & 1583.549 & $0.006^{* * *}$ \\
Under & -1289.547 & $0.075^{*}$ \\
Lowed & 1394.256 & $0.087^{*}$ \\
$R^{2}$ & 0.355 & $\mathrm{NA}$ \\
F statistic & 3.091 & $0.002^{* * *}$ \\
\hline
\end{tabular}

NA, not applicable.

$*$, Significant at $10 \%$.

$* *$, Significant at $5 \%$.

***, Significant at $1 \%$

\section{Appendix 2: Day labouring wage robustness model}

TABLE 1-A2: Income model with the worst monthly wage.

\begin{tabular}{lcc}
\hline Variables & Coefficient & $p$ \\
\hline Worst monthly wage & & \\
Constant & -256.927 & 0.436 \\
Negotiated & 459.426 & $0.004^{* * *}$ \\
Primary & -148.048 & 0.519 \\
Reservation & 7.295 & $0.031^{* *}$ \\
DI_exp & -19.216 & $0.087^{*}$ \\
Under & 66.642 & 0.700 \\
Hired_bricklay & 286.929 & 0.169 \\
Hired_painting & 67.033 & 0.689 \\
Hired_plumbing & 93.101 & 0.623 \\
$R^{2}$ & 0.313 & $\mathrm{NA}$ \\
$F$ statistic & 2.868 & $0.010^{* *}$ \\
\hline
\end{tabular}

NA, not applicable.

*, Significant at $10 \%$.

**, Significant at $5 \%$.

$* * *$, Significant at $1 \%$ 